\title{
Implementation of Human Rights Certification as an Application for the Protection of Human Rights to Workers in the Fisheries Industry
}

\author{
Tito Pramudita ${ }^{1}$ \\ 1 Master of Law, Universitas Indonesia, Indonesia \\ pramuditatito@gmail.com
}

\begin{abstract}
Introduction to the Problem: State responsibility is one of the important keys in the life of the state, one of which is in labor affairs. In its implementation, there are several records of human rights violations in the Indonesian Sea, namely Trafficking in Persons, Forced Labor/Slavery, Child Labor, Overtime, and the absence of health insurance.

Purpose/Objective Study: This research aims to analyze the regulations in Indonesia concerning the protection of human rights for workers in the fishing industry in Indonesia and whether the Fisheries Human Rights Certification under the Regulation of the Minister of Maritime Affairs and Fisheries Number 35 of 2015 has effectively grant human rights protection to workers in the field of fisheries fishing industry in Indonesia.
\end{abstract}

Methodology: The research method used is juridical-normative.

Findings: This study indicates that Human Rights Certification in the Fisheries Sector is one solution so that fishing companies meet the Human Rights criteria set by the Government but still need improvement in the context and implementation. Conclusion Research on Fisheries Human Rights Certification has not been effective in protecting workers in the fishing industry from a technical and conceptual perspective. Effectiveness can be improved if there is an evaluation of problems in the form of overlapping authorities between agencies, the seriousness of the Fisheries Human Rights Team in carrying out its authority.

Paper Type: Research Article

Keywords: Certification; Human Rights; Workers; Fisheries Industry

\section{Introduction}

The threat of human rights violations by corporations in Indonesia does not only apply on the ground. The Indonesian Sea, which covers $76.94 \%$ of the total area of Indonesia, is the place where many corporations operate. It is because Indonesia is a maritime country that has so much diversity of marine wealth and potential. This natural wealth is an attraction for corporations to run their business in the Indonesian fishery sector. However, behind the beauty of Indonesia's marine wealth, there is a sadness about the condition of workers in the Indonesian fisheries sector. The working hours of workers in the fisheries sector tend to be inhumane (Nowak, 2003) (Shalihah \& Nur, 2021). Pressure to work up to 22 hours a day for seven days 


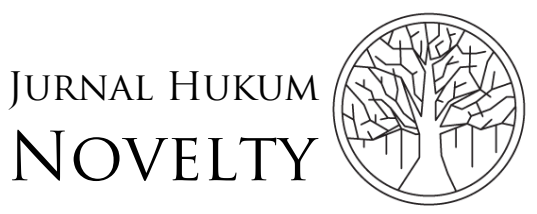

Volume 12, Issue 02, 2021, pp. 171-190

P-ISSN: $1412-6834$

E-ISSN: 2550-0090

per week with only about 2-4 hours of rest per day, coupled with exhausting physical exertion that is not in accordance with applicable labor regulations (Adam, 2017).

The working hours are so tight and the physical work is so hard that many workers often fall sick. However, they do not receive adequate medical care (Dharmawirawan \& Modjo, 2012). Not infrequently, some workers died because they did not get treatment. Salaries and overtime pay are rarely paid to workers on time (Nur \& Susanto, 2021), even for years. This condition left them with no other choice but to keep working on the ship, as they had no money on their hands. Things that are important for workers, such as health insurance and adequate facilities, are never given because they are considered insufficient and are not seen as things that should be provided for workers.

Responding to the serious human rights violations experienced by workers in the Indonesian marine fisheries sector, the Government of Indonesia, through the Ministry of Maritime Affairs and Fisheries, stipulates the Minister of Marine Affairs and Fisheries Regulation Number 35 of 2015 concerning Fisheries Human Rights System and Certification (Nur \& Susanto, 2021). Its ratification was announced on 10 December 2015 to coincide with the commemoration of International Human Rights Day by Susi Pudjiastuti as Minister of Maritime Affairs and Fisheries of the Republic of Indonesia for the 2014-2019 period. Indonesia encourages the implementation of respect for human rights by corporations as regulated in the United Nations Guiding Principles on Business and Human Rights (UNGP).

The International Labor Organization (ILO) states that the fisheries sector is the most vulnerable to human rights violations for its workers, especially in the fisheries sector. If we look at the condition of workers in the Indonesian fishery sector, this statement is true (Darulízain, 2017). There are various types of human rights violations experienced by workers in the fisheries sector in Indonesia, especially slavery. The Benjina case is a slavery case that occurred in the Arafura Sea, where hundreds of crew members from various countries from Myanmar and Cambodia became victims. The definition of slavery itself can be found in the general explanation of Law Number 21 of 2007 concerning the Crime of Trafficking in Persons. In this law, the meaning of slavery is as follows:

"Slavery is the condition of a person being under the possession of another. A slavery-like practice is an act of placing a person in the power of another so that th person cannot refuse work that someone else has illegally ordered, even if that person does not want it."

Slavery/trafficking in persons is one of the worst forms of treatment that violates human dignity. The prohibition of slavery/trafficking in persons is regulated in Article 2 of Law Number 21 of 2007 concerning the Crime of Trafficking in Persons and Article 4 and Article 20 of Law Number 39 of 1999 concerning Human Rights (Darulzain, 2015). One of the civil and political rights listed in the ICCPR as an international instrument on civil and political rights is the right to be free from 
slavery. Article 8 of the ICCPR explains that no one can be enslaved (Darulzain, 2015).

The potential for human rights violations against workers in the fisheries sector occurs at least due to 2 (two) factors, such as ignorance and the necessities of life. The history of the fixed-term employment contract (PKWT, Perjanjian Kerja Waktu Tertentu) is based on an agreement that the type and nature of its activities are only temporary. Unfortunately, many workers in the fisheries sector and entrepreneurs do not know the contents or clauses in the PKWT and the consequences if there is bad faith from the entrepreneur (Braam, 2019). This general ignorance is usually related to the temporary nature of the provisions in Article 56 paragraph (2) and 59 paragraph (2) of Law Number 13 of 2003 concerning Manpower.

Apart from ignorance, the reason for the necessities of life is also a factor that is no less important. Globally, start-up workers and boats are faced with tough jobs and competition for jobs (Nasution, 2019). Monotonous skills or soft skills also narrow the choice to choose the type of work in other fields. In particular, anthropological fishery workers come from coastal areas, and they tend to have expertise in matters related to marine and fisheries (Imron et al., 2018).

The causes of accidents on fishing vessels include low awareness of crew members about work safety in shipping and fishing activities, low mastery of shipping competence and fishing safety, ships not equipped with proper safety equipment, bad weather such as big waves, and suffering from serious injuries illnesses during delivery. Therefore, the knowledge and skills of the crew, and equipment for safety and ship worthiness, must be a concern for the crew and fishing vessel entrepreneurs. Knowledge and skills about the safety of crew members can minimize the risk of premature accidents and accidents that have occurred so as to avoid unwanted fatal consequences (Suwardjo et al., 2017).

How do human rights relate to maintaining fish stocks, the flow of economic and nutritional benefits from fisheries, or supporting communities and cultures that depend on fish? These questions often precede attempts to explain why the human rights approach has something useful to offer in current policy reforms to preserve viable fisheries and increase their contribution to human well-being. For many, the mention of human rights conjures up images of the struggle for the right to speak freely without fear of arrest or torture, the right to a fair trial, or the rights of minorities. Human rights, however, are more than just political and civil rights. They also include a set of "economic, social and cultural rights," which includes decentralized rights to food, water, housing and work, and the rights of children, migrants, and women. Each of these rights has a supporting legal framework that forms the architecture of international human rights law (Lewis et al., 2017).

Heavy working hours and strenuous physical work often make workers sick, but employers do not provide adequate health care or insurance. Therefore, it is not uncommon for workers to die because they do not get proper treatment and health 
services. This condition causes the workers to have no other choice but to work on ships because they do not have spare money to live on. Law No. 13 of 2003 concerning Manpower (Manpower Law) Article 77 paragraph (2) regulates seven working hours in one day, and eight working hours in one day or 40 (forty) working hours in a week.

According to Soepomo in Abdul Hakim, labor protection can be divided into three types, namely (Hakim, 2003): 1) Economic Protection; 2) Social Protection; and 3) Technical Protection. The "rights-based approach," which reflects the form of protection proposed by Soepomo for development, argues that human rights are integral to development outcomes. International human rights norms highlight the freedom and capabilities of each individual, an important component of the human development side that realizes the rights of the poor for an adequate standard of living, work, health care, and education. It also establishes the legal and moral basis for development efforts and enables alternative investment priorities or policy choices based on how effective they contribute to the fulfillment of these human rights needs.

Furthermore, the analysis of civil and political rights offers an opportunity to assess society's power relations livelihood options and which can hinder sustainable development. In its application to natural resource management, the human rightsbased framework draws attention to the institutions and power structures that determine the allocation and access of resources. Human rights advocacy to establish the right of access to natural resources for the poor, as part of their right to livelihood, is a legal and moral requirement that cannot be easily rejected (Ratner et al., 2014).

The recent status "a quo" as described above ultimately requires the government's attention to workers in the fishing industry. Moreover, the decline in productivity in the fisheries sector and intense competition in the global arena have made the fishing industry more complex. Therefore, real intervention from the Government is needed to help improve the welfare of workers in the fishing industry (Nowak, 2003).

On 10 December 2015, coinciding with International Human Rights Day, there was hope for workers in the fishing industry in Indonesia. Through the Ministry of Maritime Affairs and Fisheries, Susi Pudjiastuti, the Government of Indonesia had issued Regulation No. 35 of 2015 concerning Fisheries Human Rights Regulation and Certification. This provision is the first regulation in Indonesia that encourages respect for human rights by entrepreneurs as regulated in the United Nations Guiding Principles on Business and Human Rights (UNGP) (Alimuddin, 2001).

This research aims to analyze the regulations in Indonesia concerning the protection of human rights for workers in the fishing industry in Indonesia and whether the certification of human rights in the fishery sector under the Regulation of the Minister of Maritime Affairs and Fisheries Number 35 of 2015 has effectively provided human 
rights protection to workers in the fishing industry in Indonesia. (Allison, 2011).

Theoretically, the results of this study are expected to provide advice in the form of practical knowledge related to the protection of human rights for workers in the fishing industry in Indonesia. Practically, the results of this research are expected to contribute to the community, especially legal actors related to the Fisheries Human Rights Certification as stipulated in the Minister of Marine Affairs and Fisheries Regulation Number 35 of 2015.

\section{Methodology}

This research on the implementation of human rights certification as a form of protection of human rights for workers in the fishing industry is normative-juridical research, better known as library law research. In addition, this research is also equipped with a statutory approach, a case approach, and a comparative approach so that this research is not limited to research on applicable law (normative), but more than that is how the law should be applied.

\section{Results and Discussion}

\section{Regulation and Implementation of the Concept of Human Rights in the Fisheries Business in Indonesia}

In order to carry out its obligations to protect human rights, especially in the field of fisheries, the Government, through the Ministry of Maritime Affairs and Fisheries, issued Regulation of the Minister of Marine Affairs and Fisheries Number 35/PERMEN-KP/2015 concerning Systems and Certification of Human Rights in Fisheries Business (Permen KP 35/2015). The requirements and certification mechanism regulated in the Minister of Marine Affairs and Fisheries Regulation Number 2/PERMEN-KP/2017 concerning Requirements and Procedures for Fisheries Human Rights Certification. The background of this regulation is as follows (Rahmatullah, 2018): 1) Evidence of gross human rights violations in the Indonesian fishery business in Benjina and Ambon, Indonesia; 2) United Nations Guiding Principles on Business and Human Rights (2011) and ILO Convention No. 188 of 2007 provide international guidance for countries to implement responsible business and human rights \& fisheries practices; and 3) Indonesia ratified two main rights treaties: ICCPR and ECOSOC.

The state must be interpreted to include the notion of being controlled by the state in a broad sense originating from the conception of Indonesian people sovereignty over all sources of wealth "earth, water, and the natural resources contained therein," including the definition of public ownership by people's collectivities of resources -the source of the wealth. The people who are collectively constructed by the 1945 Constitution mandate the state to carry out five things:

1. Policy function (beleid).

2. Management function (bestuursdaad).

3. This function is carried out by the Government with the authority to issue and 
revoke permit (vergunning), license (licentie) and concession (consessie) facilities.

4. Setting function (regelendaad). This function is carried out by legislative authority, the House of Representatives and Government, and the regulation by the Government.

5. Management function (beheersdaad). This function is carried out through a share ownership mechanism and/or as an institutional instrument, in which the state, in this case, the Government, makes full use of its control over these resources for the greatest benefit of the people's prosperity.

6. Supervision function (toezichthoudensdaad) for the greatest prosperity of the people. This function is carried out by the State, in this case, the Government, in the context of supervision and control so that the implementation of control by the state over such assets is truly carried out for the greatest prosperity of the people.

The Ministerial Regulation on Fisheries is the first regulation that compels and requires fishery entrepreneurs specifically to respect the human rights of crew members in fishery business activities, where sanctions for violations of human rights committed by fisheries entrepreneurs against their crew members can have a direct impact on their business activities, namely:

1. Freezing of fishery business licenses, fish-catching permits and/or fish transport ship permits;

2. Revocation of fishery business license, fish-catching permit and/or fish transport ship permit; and/or

3. Recommendation for revocation of permit to use labor to the Ministry of Manpower.

This regulation supports one of the government's programs, in order to bring back the state to protect the entire nation and provide a sense of security to all citizens, through a free and active foreign policy of trusted national security and the development of an integrated Tri Matra state defense based on the interests of the nation and strengthen our identity as a country team. In addition, this regulation was prepared with reference to the UNGP. The UNGP is a global standard developed by John Ruggie, the UN Secretary General's special representative on Business and Human Rights, authorized to prevent and demonstrate the risks of adverse human rights impacts associated with business activities. The scope of this regulation covers the Fisheries Human Rights System and Fisheries Human Rights faction. The main implementer of this regulation is the Fisheries Human Rights Team formed by the Ministry of Maritime Affairs and Fisheries. The Fisheries Human Rights Team has the duty in certain accrediting institutions to become Research Institutions and the Appraisal Agency.

Pela Institute is in charge of giving training to corporations regarding implementing the fisheries human rights system in corporate operations. At the same time, the Assessment Agency is tasked with assessing whether a corporation has succeeded in 
implementing the fisheries human rights system and deserves certification. Fishery human rights certificate from the Minister of Marine Affairs and Fisheries.

The fishery human rights law is only valid for three years, so fishery entrepreneurs must extend it if the time limit has expired. It means that there will be regular evaluations from the Fisheries Human Rights Team and assessment agencies that the Fisheries Human Rights Team has accredited on the Fisheries Human Rights System carried out by fisheries entrepreneurs. Therefore, fishery entrepreneurs must carry out the Fishery Human Rights System as well as possible continuously so that they can not only have a Certificate of Fisheries Human Rights but also extend it if the time limit has expired. According to this fact, fishery entrepreneurs will not be able to run their fishery business in the marine territory of the Unitary State of the Republic of Indonesia (NKRI).

The discussion of modern slavery related to human rights means discussing how to protect victims of modern slavery who experience worker exploitation, discrimination, harassment, and human trafficking. Considering the issue of human rights is a global issue and problems of democracy and the environment. Therefore, this is a severe concern for the government to be able to protect, respect, defend and guarantee the human rights of citizens and all Indonesians without discrimination in any form. It is emphasized in Law Number 39 of 1999 that human rights are rights that have been attached to humans as creatures of God Almighty and are a gift that must be respected and upheld. The state, government, and every citizen are obliged to protect it for the fulfillment of honor, dignity, and human dignity. To achieve this goal, integrated and effective law enforcement is needed to support the protection of human rights.

The protection and enforcement of modern slavery are the same as law enforcement against the criminal act of trafficking in persons, with the existence of law enforcement regulated in the criminal act of trafficking in persons in Indonesia in the form of punishment of the perpetrators, namely in the form of:

1. imprisonment;

2. imprisonment;

3. fines;

4. restitution.

Other protection provided to victims for recovery after acts of human rights violations can be in the form of rehabilitation, be it medically, psychologically, and socially, returning victims to their places of origin, as well as integration that the state must carry out. This law stipulates that the government, local governments, communities, families, and the formation of a task force to deal with victims of trafficking in persons and prevent the occurrence of trafficking in persons.

Five forms of state control, namely the functions of policy and administration, 


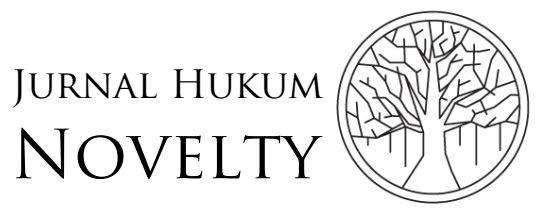

Volume 12, Issue 02, 2021, pp. 171-190

P-ISSN: $1412-6834$

E-ISSN: 2550-0090

regulation, management, and supervision, are placed in the same position. Suppose the Government only carries out one of the four functions of state supervision, for example. In that case, it only carries out the function of regulating, even though regulating is a general function of the state in any country without the need for Article 33 of the 1945 Constitution. It does not necessarily mean that the state has exercised control over natural resources because state control does not achieve the maximum goal for the prosperity of the people, as referred to in Article 33 of the 1945 Constitution (Derman \& Ferguson, 1995).

This shows the desire of the Indonesian people to utilize its potential for the benefit of people's prosperity and welfare. One of the potentials that can be utilized for national development is the natural wealth found in the Indonesian seas. Indonesia is the largest archipelagic country in the world, which has 17,504 islands spread from Sabang to Merauke, with a beach length of $99,093 \mathrm{~km}$ which ranks 4th in the world after Canada $(265,523 \mathrm{~km})$, the United States $(133,312 \mathrm{~km})$, and Russia $(110,310 \mathrm{~km})$ (KKP, 2014). Therefore, it is very natural that the Indonesian constitution states that Indonesia is an archipelagic country.

Suppose it can demonstrate its ability to enforce sovereignty in its own territorial waters, fight for sovereignty at sea, and play an active role in fighting for its interests over marine resources in the international sea. In that case, apart from being the largest archipelagic country globally, Indonesia can also be called a maritime country. At least 3 (three) main things, namely the enforcement of sovereignty, the exercise of authority, and interests, are the keys to making Indonesia a maritime country or maritime axis. Five pillars must be considered: 1) Indonesia will rebuild Indonesia's maritime culture, 2) Indonesia will maintain and manage marine resources, 3) Indonesia will prioritize infrastructure development and maritime connectivity by building roads sea highways.

Regulations regarding the prohibition of modern slavery regulated in the 1945 Constitution of the Republic of Indonesia; the Human Rights Law, and the Manpower Law are not sufficient to protect the human rights of workers by certain elements, especially for workers. In the fishery sectoral, with these factors, the Ministry of Maritime Affairs and Fisheries of the Republic of Indonesia established three (3) ministerial regulations, including:

1. Regulation of the Minister of Maritime Affairs and Fisheries of the Republic of Indonesia Number 35 of 2015 concerning Human Rights Systems and Certificates in Fisheries Business (Permen KP Human Rights Regulation). This regulation requires every entrepreneur in the fisheries sector to implement a fisheries human rights system and must have a fisheries human rights certificate. It aims to respect the parties' human rights related to fishery business activities and the surrounding community. This regulation has covered the implementation of the Human Rights System related to human rights policies, due diligence on human rights, and restoration of human rights. 
2. Regulation of the Indonesian Minister of Maritime Affairs and Fisheries Number 42 of 2016 concerning Sea Work Agreements for Fishing Vessel Crews was formed based on Article 5 paragraph (2) letter c Permen KP Human Rights Regulation for fisheries. This regulation also complements the system and Fisheries Human Rights Certificate, which seeks to prevent the occurrence of modern slavery in Indonesia's fishing industry. PKL contains an agreement on work requirements, work eligibility guarantees, wage guarantees, health insurance, accident, and disaster insurance coverage, security guarantees, and legal guarantees based on the provisions of the applicable legislation. It is expected to protect the crew from violations of human rights.

3. Regulation of the Indonesian Minister of Maritime Affairs and Fisheries of the Number 2 of 2017 concerning Requirements and Mechanisms for Fisheries Human Rights Certification and Fisheries Human Rights Certificate Mechanisms were established based on Article 9 paragraph (5) of the Permen KP Human Rights Regulation on Fisheries. This regulation is more procedural. It regulates the procedure for submitting a Fisheries Human Rights Certificate so that this regulation is considered quite important. Suppose the fishery entrepreneur does not have a Fishery Human Rights Certificate or violates the requirements of human rights compliance. In that case, it can result in freezing and also revocation of Fishery Business License (SIUP), Fishing Permit (SIPI), and Fish Transport Vessel Permit (SIKPI), Recommendation for revocation permission to use labor to the Ministry of Manpower of the Republic of Indonesia.

Permen KP 35/2015 requires Entrepreneurs to implement a fisheries human rights system, which consists of a human rights policy, human rights due diligence, and human rights restoration. The human rights policy is made in a statement of commitment to comply with all laws and regulations. Meanwhile, human rights due diligence is a process carried out by fishery entrepreneurs to identify, assess, prevent, reduce, and address the impacts of human rights violations arising from fisheries entrepreneurs' activities, operations, and business relationships (Derman \& Ferguson, 1995).

Furthermore, the restoration of human rights is a process that aims to resolve the impact of human rights violations caused or followed by fisheries entrepreneurs through an effective judicial and non-judicial complaint mechanism. In implementing the Human Rights Due Diligence, Fishery Entrepreneurs must meet the following criteria for fulfilling fisheries human rights:

1. occupational safety and health of fishery businesses, in the form of:

a) availability of procedures to ensure occupational safety and health;

b) availability of occupational safety and health experts;

c) the availability of adequate accommodation and adequate nutrition for workers and crews of fishing vessels;

d) fulfillment of requirements for work equipment and supplies for fishery entrepreneurs to ensure occupational safety and health; and 
e) implementation of occupational safety and health training for workers and crews of fishing vessels;

2. The recruitment system for Fishing Vessel Workers and ABK is in the form of:

a) procedures that ensure the recruitment of Fishery Vessel Workers and Crews;

b) fulfillment of minimum age and competency requirements for Fishery Vessel Workers and Crews; and

c) application of work agreements and sea work agreements.

3. The workforce system, in the form of:

a) fulfillment of the requirements of the collective labor agreement or company regulations;

b) fulfillment of health and work accident insurance for workers;

c) fulfillment of social security requirements;

d) fulfillment of collective work requirements or company regulations;

4. sustainable community development responsibilities, in the form of:

a) create job opportunities for the surrounding community; and

b) improve the standard of living of the local community.

5. security system, in the form of:

a) organize human rights training for security forces; and

b) integration of elements of human rights into security work procedures.

6. environmental management system, in the form of:

a) prevention of environmental pollution; and

b) maintenance of biodiversity.

7. land acquisition system, in the form of:

a) fulfillment of requirements to avoid forced land acquisition; and

b) fulfillment of requirements for reasonable reimbursement.

This human rights system is expected to be a form of human rights protection from the government and proof of respect for human rights by fisheries entrepreneurs. Through Permen 35/2015, every fishery entrepreneur must comply with the Human Rights System on paper and implement it. After the fishery entrepreneur applies the entire fisheries human rights system and is declared to have passed the human rights certification, the Minister issues a human rights certificate to the fishery entrepreneur (Kirchner, 2019).

This Fisheries Human Rights Certificate is valid for 3 (three) years. Based on the delegation of authority from the Minister, the Head of the Fisheries Human Rights Team will issue a human rights certificate (Allison, 2011). This certification procedure begins with the fulfillment of the Fisheries Human Rights System by the Fishery Entrepreneur, who then requests the implementation of the Fisheries Human Rights certification assessment to the Head of the Fishery Human Rights Team. After that, the head of the Fisheries Human Rights Team will appoint an Appraisal Agency, but if there is none, the assessment will be carried out by the Fisheries Human Rights Team. 
The application letter is then verified by the Head of the Fisheries Human Rights Team no later than 7 (seven) working days after the documents are complete. After that, it will be determined whether the application is rejected because it is incorrect, returned because it is incomplete, or a human rights certification assessment can be carried out (Allison, 2011). If the assessment can be carried out, the Fishery Entrepreneur makes a work contract with the Appraisal Agency, and then the Appraisal Agency will carry out its duties. The assessment was carried out based on documentation of the Fishery Human Rights System results, field monitoring, and interviews. The final result of the report is conformity and non-conformity. If the results are appropriate, the Assessment Body will recommend issuing a fishery human rights certificate to the Head of the Fisheries Human Rights Team. After that, the Human Rights Fisheries Team will verify that a Human Rights Certificate will be issued if the requirements are complete and correct.

This Human Rights Certificate is the same as the concept of The Marine Stewardship Council program, which is one of the international non-profit organizations engaged in human rights in the fisheries sector that provides a Certificate of Human Rights in the form of a Certificate of Human Rights Report Rights at sea. This report focuses on the tragic death of Eritara Aati Kaierua, a Kiribati observer of the Taiwan-flagged and Win Far 636-registered tuna ring trawler, who was on her way to catch tuna from MSC certified PNA skipjack and yellowfin tuna fisheries in the Western and Central Pacific Ocean. The death of Eritrean Aati Kaierua was a tragic and shocking event. The first death of a bystander onboard authorized under the PNA ship day scheme is to capture eligible MSC-certified catch. Furthermore, it is now under ongoing police investigation.

Two companies operating in the region hold fisheries certificates and the MSC Group Chain of Custody Certificate for tuna fisheries, the PNA Western Pacific Sustainable Tuna Alliance (WPSTA), and the PNA Office. Upon learning of the death of Eritara Aati Kaierua, both companies terminated the Win Far 636 program. They took steps to ensure that no catch from the vessel then enters the supply chain as MSC certified catch.

The tragedy shows that the existence of a Certificate of Human Rights plays an important role in the world of fisheries, especially in ensuring the human rights of the fishery sector itself. Several reports highlight that some fishing industry sectors continue to use forced labor and corporal punishment, even killing workers on purpose. Fishermen can be especially vulnerable at sea, out of sight of law enforcement agencies or the help of friends and family. Changes in the industry have exacerbated the problem. Factory ships, first seen in the whaling industry, are now commonly seen processing fish in the waters of many states. Smaller fishing vessels now visit them to unload their catch rather than returning to shore on their own. Forced labor has even been reported in coastal waters of countries with much stronger worker protections, such as the UK and New Zealand. These violations are 


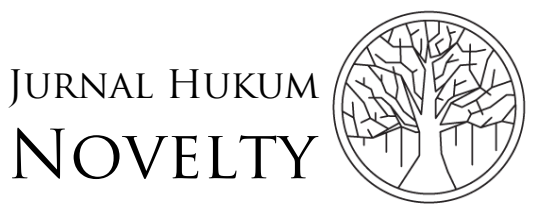

Volume 12, Issue 02, 2021, pp. 171-190

P-ISSN: 1412-6834

E-ISSN: 2550-0090

still largely invisible to people buying seafood or fish-based products, including dietary supplements and pet food. Most people would be surprised to learn that their purchase helps keep an unscrupulous business going.

In the context of Indonesia, the general rule applies that a work agreement between an entrepreneur and a worker/laborer is based on a work agreement that contains the working conditions, rights, and obligations of the parties who fulfill the legal requirements of the agreement as stipulated. in Article 1320 of the Code. Civil. In addition, the labor regulations in Law Number 13 of 2003 concerning Manpower are general in nature, so they also apply to workers at sea. Article 145 of the Shipping Law provides a limitation that anyone is prohibited from employing someone on a ship in any position without permission and without having the required competencies and skills as well as the required seafarer documents. In addition, Article 337 of the Shipping Law itself also confirms that the labor provisions in the shipping sector are carried out in accordance with the laws and regulations in the manpower sector. Thus, this provision supports our previous statement regarding applying the Manpower Act for workers at sea/onboard ships. Thus, the rights and obligations to work in the fisheries sector are also reflected in the Manpower Act. Meanwhile, it was reaffirmed that the working hours recognized in the Manpower Act are 40 hours per week (Braam et al., 2019).

The lack of state attention in fisheries makes fishermen or seafarers exceed the working hours regulated in the Manpower Act. It is caused by several factors which are dominated by the needs of the seafarers themselves. In addition, another factor that causes this is the existence of a Marine Work Agreement (PKL) that does not reflect seafarers' welfare. However, what needs to be emphasized, the purpose of the formulation of street vendors is to ensure the fulfillment of working conditions, work conditions, wages, health insurance, accidents, accidents, death insurance, legal guarantees, and fishing vessel safety guarantees crew and to ensure:

1. protection and welfare of fishing vessel crews; and

2. The fishing vessel crew employed have competence, fishing vessel crew documents, and are willing to work.

The Ministerial Regulation on Fisheries is the first regulation that compels and requires fishery entrepreneurs to respect the human rights of ship crews in fishery business activities. Sanctions for human rights violations committed by fisheries entrepreneurs against their subordinates can have a direct impact on their business activities:

1. suspension of fishery business license, fish-catching permit and/or fish transport ship permit;

2. revocation of fishery business license, fish-catching permit and/or fish transport ship permit; and/or

3. recommendation for revocation of labor utilization permit to the Ministry of Manpower. 
This regulation supports one of the government's Nawa Cita programs, namely "Returning the country to protect the entire nation and provide a sense of security to all citizens, through an active foreign policy, reliable national security, and the development of an integrated Trinity. The national defense dimension is based on national interests and strengthens its identity as a maritime nation". In addition, this regulation was prepared with reference to the UNGP. UNGP is a global standard developed by John Ruggie, the UN Secretary General's special representative on Business and Human Rights, authorized to prevent and address the risks of adverse human rights impacts associated with business activities.

The scope of this regulation covers the Fisheries Human Rights System and Fisheries Human Rights Certification. The main implementer of this regulation is the Fisheries Human Rights Team formed by the Ministry of Maritime Affairs and Fisheries. The Fisheries Human Rights Team has the task of certain accrediting institutions to become Assessment Agencies and Agencies. The Pagian Agency is tasked with providing guidance to corporations regarding implementing the fisheries human rights system in corporate operations. In contrast, the Assessment Board is tasked with assessing whether a corporation has successfully implemented the fisheries human rights system and deserves an award fishery human rights certificate from the Minister of Marine Affairs and Fisheries.

\section{Critical Analysis of Fisheries Human Rights Certification as Stipulated in the Regulation of the Minister of Maritime Affairs and Fisheries Number 35 of 2015 Has Effectively Provided Human Rights Protection to Workers in the Fishing Industry in Indonesia}

In the fisheries industry, three agencies play an important role, namely the Ministry of Maritime Affairs and Fisheries (KKP), the Ministry of Manpower (Kemenaker), and the Ministry of Transportation (Kemenhub) (Nur, 2021). Article 9 of Permen KP Number 35 of 2015 states that Fisheries Human Rights Certification is given to Fisheries Entrepreneurs by the Fisheries Human Rights Team. A Minister forms the Fisheries Human Rights Team, but it is not explained in detail in this regulation. Permen KP Number 35 of 2015 is a technical regulation that must explain in detail what, who, why, when, and how the spirit of protecting human rights in the fisheries sector can be implemented (Getchell, 2017).

The role of the Fishery Human Rights Team coordinator, which is still tentative, has an impact on the overall performance of the Fisheries Human Rights Team. The Fisheries Human Rights Team consists of one agency and is an inter-agency consisting of elements of ministries, non-ministerial government agencies, and nongovernmental organizations.

In addition, Article 5 of Permen KP Number 2 of 2017 states that the technical provision of Fisheries Human Rights Certificates is again delegated to the Appraisal Agency. Thus, there is a complicated bureaucratic mechanism for delegation: starting 
from the Minister to the Fisheries Human Rights Team to verify the required documents, then delegating them to the Assessment Agency to be audited externally regarding the implementation of human rights. In its implementation, there is the potential for overlapping.

The Fisheries Human Rights Team is a form of protection and respect for human rights from the state through the Minister of Fisheries Industry. The Fisheries Human Rights Team consists of various agencies, namely elements of ministries, nonministerial government agencies, and related non-governmental organizations that are formed in a transparent, participatory, and accountable manner. The Fisheries Human Rights Team must also come from representatives of workers and representatives of employers to provide an accurate picture of the problems faced in the fishing industry. However, the regulation does not provide clear space for the two representatives as part of the Fisheries Human Rights Team structure.

The Fisheries Human Rights Team as a whole is at the forefront of protecting human rights in the fisheries sector because it is authorized by regulations, namely: Determining the requirements and criteria for implementing and supervising fishery human rights certification; Accrediting assessment agencies to carry out assessment tasks in the field of fisheries human rights certification, human rights training institutions to conduct fisheries human rights certification training for assessment agencies, and other supporting institutions; grant, refuse, suspend, and revoke fishery human rights certificates to fishery entrepreneurs; and Carry out other duties and functions assigned by the Minister in the context of protecting and respecting human rights of fisheries (Simanjuntak \& Syaputra, 2019).

Since Permen KP No. 35/2015 was promulgated on 8 December 2015 and further arrangements were made through Permen KP No. 2 of 2017 on 23 January 2017, in fact, the Fisheries Human Rights Team was only active in the middle of 2019. With the establishment of a new Fisheries Human Rights Team, the Appraisal Agency that has been selected in collaboration with the Fisheries Human Rights Team is still at a conceptual level. In terms of legal substance, efforts have been made to improve regulations to achieve high safety standards for PPAs on fishing vessels. Currently, two pillars have been finalized and ratified: the Port State Measures Agreement to Prevent, Deter, and Elimination Illegal, Unreported and Unregulated Fishing; and the Standard Convention on the Training, Certification, and Supervision Fishing Vessel Personnel (STCW-F). Meanwhile, two other pillars are currently being finalized by the Government of Indonesia, namely the Cape Town Agreement on Safety of Fishing Vessel Convention; and ILO Convention No. 188 concerning Employment in the Fisheries Sector.

With the rearrangement of the assessment from the Fisheries Human Rights Team to the Assessment Agency, the bureaucratic flow of Human Rights Certification has become complicated and convoluted. Meanwhile, the initial concept of forming the 
Fisheries Human Rights Team was to assess the human rights criteria of fishery entrepreneurs themselves. In the end, the Fisheries Human Rights Team only provided document validation to fishery entrepreneurs. In contrast, the Fisheries Human Rights Team consisted of people who had experience in the fields of law, maritime affairs, and fisheries. Even the Fisheries Human Rights Team seems lazy to work because it has handed over its main authority to an independent Appraisal Agency and only confirmed recommendations from the appointed Appraisal Agency.

In addition, there are not many Assessment Agencies that focus on marine and fisheries in Indonesia and are not yet competent. Assessment agencies in Indonesia focus on Inspection and Management Agencies in general. In contrast, the assessment agencies for Fisheries Human Rights Certification must really understand the core business of the fishing industry so that they can fully understand the challenges and problems faced by workers and employers.

Referring to the provisions of Article 5 Paragraph (1) Permen KP No. 2 of 2017, it is stated that to obtain a fishery human rights certificate, fishery entrepreneurs must first apply a human rights system to fishery businesses. The provisions of this article seem to force fish entrepreneurs to understand human rights criteria standards (Simanjuntak \& Syaputra, 2019). As for fish entrepreneurs, the term human rights is a term that is rarely heard, especially how it is applied in the fisheries business.

Before being directed to obtain Human Rights Certification, both Workers and Entrepreneurs in the fishery sector are given education about the basic human rights of a person in working and employing people. The concept of Human Rights that is understood has made the policy direction regarding Human Rights Certification easier to understand by all parties and is not just an examination of legalistic documents. However, in organizing the event, there are some critical notes from the author as evaluation material. First, the training is only aimed at fish entrepreneurs in the format of preparing documents and requirements in applying for fishery human rights certification. It means that workers in the fishery sector are not included in the training program. Whereas the original purpose of the Fisheries Human Rights Certification was more than just a standard human rights document, but it must be implemented so that there is protection for workers in the fishery sector. Workers must be massively involved in this training to know their rights as workers in the fishing industry (Nur \& Susanto, 2021). The training was carried out partially in several regions in Indonesia. This training must be implemented massively for entrepreneurs and workers throughout Indonesia so that the initial goal of educating all entrepreneurs in the fisheries sector can be achieved.

Supervision aims to obtain the results of the implementation of activities efficiently and effectively following a predetermined plan. It is in accordance with the opinion of Handayaningrat, who said that "Supervision aims to obtain the results of the implementation of work efficiently and effectively, in accordance with a 
predetermined plan." Supervision aims to determine whether the implementation of the work has been in accordance with what was planned, whether all instructions have been implemented, and what difficulties are encountered (Soekarno, 1985). According to Soekarno, there are several objectives in conducting supervision, namely: 1) To find out whether something is going according to the plan that has been outlined;2) To find out whether everything is done according to the instructions and principles that have been instructed; 3) To find out the difficulties, weaknesses, weaknesses in work; 4) To find out if everything is running efficiently; and 5) Finding a way out, if difficulties, difficulties, weaknesses or failures are found, lead to improvements".

Human Rights Certification Oversight also suffers the same fate. Referring to Permen KP 35/2015, it is known that the Human Rights Certification was found after going through a standardized legal document due diligence process and field monitoring. Fish entrepreneurs who have passed the Human Rights Certification can use the Human Rights Certification for 3 (three) years. After obtaining Human Rights Certification, the provisions in Permen KP 35/2015 do not explain the mechanism for periodic monitoring of the development of Fisheries Entrepreneurs' compliance. The supervisory mechanism is only regulated in Chapter V of Permen KP 35/2015, carried out incidentally. It is also done in order to prevent overlapping in terms and sectors of authority.

The overlapping authority is an obstacle that has great potential to be faced to guarantee respect for the human rights of crew members. There are three main government agencies involved in the management of crew recruitment and placement in Indonesia. The three agencies are the Ministry of Maritime Affairs and Fisheries (KKP), the Ministry of Manpower (Kemenaker), and the Ministry of Transportation (Kemenhub) (Nur, 2018). The KKP regulates the operational aspects of fishing vessels (including licensing) and ship crews. The Ministry of Manpower has the authority to establish policies to increase labor competitiveness and productivity. Through the Directorate General of Sea Transportation, the Ministry of Transportation has the authority to formulate and implement policies related to sea transportation, including fishing activities.

There are various potentials for operational confusion due to overlapping policies of the three, not the main government agency. The following are things that are expected to experience overlap in terms of authority in the marine sector, including:

1. Source of authority;

2. registrant advice and licensing of labor agents;

3. the establishment of a branch office of an employment agency;

4. Appointment of Harbormaster;

5. Supervision of activities;

6. ship operating license;

7. Admission and recruitment of crew members; 
8. Seafarers' employment agreement;

9. surveillance system, and;

10. Penalty bearer.

The authority that is almost similar to each other also shows that implementing the Permen KP Human Rights Regulation on Fisheries is not the task of one particular institution. 187The three institutions must actively cooperate in implementing the Permen KP Human Rights Regulation on Fisheries. Supervision is a concrete action that is very important in implementing a regulation. With supervision, violations of a rule can be prevented. In Indonesian waters, marine surveillance can be said to be very minimal. The very few patrol boats and the less modern vessel monitoring technology called the Vessel Monitoring System (VMS) are not comparable to the Indonesian sea, which covers $76.94 \%$ of the total area of Indonesia. Ideally, to protect such a wide sea, it takes at least 500 patrol boats, consisting of 100 class I ships, 200 class II ships, 100 class III ships, 50 class IV ships, and 50 class V ships. Currently, there are only 232 patrol boats owned by Indonesia.

From some of the descriptions above, it can mean that there is no supervision specifically appointed to monitor the level of compliance of fishery entrepreneurs to continue to implement the human rights standards that have been set. Supervision is entrusted to ordinary fishery supervisors, porters, or other officials. Then the results of the supervision are submitted to the Fisheries Human Rights Team for follow-up. Such monitoring mechanisms are vulnerable to violations. It is because regular inspectors have their day-to-day duties that are not focused on the human rights aspects of the fishing industry. In addition, fishery entrepreneurs must report once every 1 (one) year to assess whether the human rights standards that have been set are still being implemented or ignored by porters or other officials. Then the results of the supervision are submitted to the Fisheries Human Rights Team for follow-up. Such monitoring mechanisms are vulnerable to violations. It is because the regular inspectors have their day-to-day duties that are not focused on the human rights aspects of the fishing industry.

\section{Conclusion}

Based on the descriptions in previous chapters regarding the Implementation of Human Rights Certification as a Form of Human Rights Protection for Workers in the Fisheries Industry, the authors can conclude that Indonesia has regulated the protection of human rights for workers in the fishing industry in Indonesia through Law Number 13 Years 2003 concerning Manpower; Regulation of the Minister of Maritime Affairs and Fisheries Number 35/PERMENKP/2015 concerning System and Certification of Human Rights in Fisheries Business; and Regulation of the Minister of Maritime Affairs and Fisheries Number 35/PERMENKP/2015 concerning Systems and Human Rights Certification in the Fisheries Business Sector Number 2/PERMENKP/2017. However, the Fisheries Human Rights Certification has not 
been effective in protecting workers in the fishing industry from a technical and conceptual perspective.

The suggestions that need to be submitted related to the theme of writing that is appointed are that the Ministry responsible for Human Rights Certification must evaluate the implementation and concept. Entrepreneurs in the fishing industry must apply human rights criteria that regulations in Indonesia have regulated. Furthermore, lastly for workers to actively supervise the implementation of human rights certification. Effectiveness can be increased if there is an evaluation of problems in the form of overlapping authorities between agencies, the seriousness of the Fisheries Human Rights Team in carrying out its authority, Human Rights Certification accompanied by education to workers, and regular monitoring mechanisms.

\section{Acknowledgment}

The authors would like to thank Universitas Indonesia for the resources provided to conduct this research. Sincere gratitude also goes to anonymous reviewers and editors who have provided constructive feedback so that this manuscript looks worth reading and citing. The author is very grateful for the publication of this journal as a guide to marine issues, especially those related to human slavery at sea.

\section{Declarations}

Author contribution : Working on the entire content of the script.

Funding statement : This research is funded under personal research and the authors receive no financial support for the research, authorship, and/or publication of this article.

Conflict of interest : The authors declare no conflict of interest.

Additional information : This research is intended to meet and produce a high standard of graduation from the Faculty of Law, University of Indonesia, as well as a dedication to the author in the academic perspective for the advancement of research, especially in Indonesia by providing an analysis of the case that the author conveys on the occasion of writing this academic journal.

\section{Reference}

Adam, L. (2017). Kebijakan Perlindungan Pekerja Perikanan Tangkap Indonesia. Kajian, 21(4), 321-338. https://doi.org/10.22212/KAJIAN.V21I4.782

Alimuddin, S. (2001). Hukum Perikanan di Indonesia. Sinar Grafika.

Allison, E. H. (2011). Should States and International Organizations Adopt a Human Rights Approach to Fisheries Policy? Maritime Studies, 10(2), 95-116.

Braam, D., Zhou, M., \& Hantyanto, A. A. (2019). Indonesia's Fisheries Human Rights

Certification System: Assessment, Commentary and Recommendations. International Labour Organization.

DarulÍzain, M. R. D. (2017). Perlindungan HAM Pekerja Sektor Perikanan. Gema 
Keadilan, 4(1), 128-142. https://doi.org/https://doi.org/10.14710/gk.4.1.128142

Darulzain, M. R. D. (2015). Pembebanan Tanggung Jawab Hukum terhadap Multinational Corporations (MNCs) dalam Hukum Internasional. Gema Keadilan, 2(1), 1-7. https://doi.org/https://doi.org/10.3592/2

Derman, B., \& Ferguson, A. (1995). Human Rights, Environment, and Development: The Dispossession of Fishing Communities on Lake Malawi. Human Ecology, 23(2), 125-142. https://doi.org/10.1007/bf01191646

Dharmawirawan, D. A., \& Modjo, R. (2012). Identifikasi Bahaya Keselamatan dan Kesehatan Kerja pada Penangkapan Ikan Nelayan Muroami. Kesmas: National Public Health Journal, 6(4), 185. https://doi.org/10.21109/kesmas.v6i4.98

Getchell, M. (2017). International Organization for Migrants, Trafficking Persons in The Finshing Industry. International Conference on Human Rights and Business in The Fishing Industries Held by FIHRSST and Ministry of Ministry of Marine Affairs and Fisheries Republic of Indonesia, 88.

Hakim, A. (2003). Pengantar Hukum Ketenagakerjaan Indonesia. PT. Citra Aditya Bakti.

Imron, M., Nurkayah, R., \& Purwangka, F. (2018). Pengetahuan dan Keterampilan Nelayan tentang Keselamatan Kerja di DPP Muncar, Banyuwangi. Jurnal Penelitian Perikanan Laut, 1(1), 99-109. https://doi.org/10.29244/core.1.1.99109

Kirchner, S. (2019). Human Rights and Fishing: A Multidimensional Challenge. Baltic Journal of Law \& Politics, 12(1), 155-171. https://doi.org/10.2478/bjlp-20190007

Lewis, S. G., Alifano, A., Boyle, M., \& Mangel, M. (2017). Human Rights and the Sustainability of Fisheries. In Conservation for the Anthropocene Ocean (pp. 379396). Elsevier. https://doi.org/10.1016/B978-0-12-805375-1.00018-0

Nasution, A. S. A. (2019). Perbudakan dalam Hukum Islam. AHKAM : Jurnal Ilmu Syariah, 15(1). https://doi.org/10.15408/ajis.v15i1.2852

Nowak, M. (2003). Introducon to the Internaonal Human Rights Regime. Brill | Nijhoff.

Nur, M. (2018). Recommendation for Authorization Overlaping of Placement of Indonesian Fishing Vessels Crews Abroad. Jurnal IUS Kajian Hukum Dan Keadilan, 6(1), 1. https://doi.org/10.29303/ius.v6i1.532

Nur, M. (2021). Slavery of Indonesian Migrant Fishers: A Review of Regulation and Its Implementation. Yustisia Jurnal Hukum, 10(2), 145. https://doi.org/10.20961/yustisia.v10i2.53715

Nur, M., \& Susanto, M. H. (2021). Certification of Fisheries Human Rights and Its Impact to Protecting the Rights of Fishing Vessel Crew. Legality: Jurnal Ilmiah Hukum, 29(1), 63-81. https://doi.org/10.22219/LJIH.V29I1.14652

Rahmatullah, I. (2018). Human Rights Due Diligence toward the Corporation of Fishery Sector in Indonesia. Proceedings of 1st International Conference of Law and Justice - Good Governance and Human Rights in Muslim Countries: Experiences and Challenges (ICLJ 2017). https://doi.org/10.2991/iclj-17.2018.14 
Ratner, B. D., Åsgård, B., \& Allison, E. H. (2014). Fishing for justice: Human rights, development, and fisheries sector reform. Global Environmental Change, 27, 120-130. https://doi.org/10.1016/j.gloenvcha.2014.05.006

Shalihah, F., \& Nur, M. (2021). Human Rights Violation Against the Indonesian Migrant Fisheries Crew in Chinese-Flagged Long Xing Vessel. Yustisia Jurnal Hukum, 10(1), 67. https://doi.org/10.20961/yustisia.v10i1.46515

Simanjuntak, I. K., \& Syaputra, M. Y. A. (2019). The Concept of Recovery on Human Rights Due Diligence by Corporation in Indonesia. Proceeding ICOPOID 2019 The 2nd International Conference on Politic of Islamic Development, 1(1), 1-12. http://proceeding.uma.ac.id/index.php/icopoid/article/view/21

Soekarno. (1985). Dasar-Dasar Manajemen, Cetakan XIV. Miswar.

Suwardjo, D., Haluan, J., Jaya, I., \& Poernomo, S. H. (2017). Keselamatan Kapal Penangkap Ikan, Tinjauan dari Aspek Regulasi Nasional dan Internasional. Jurnal Teknologi Perikanan Dan Kelautan, 1(2), 1-13. https://doi.org/10.24319/jtpk.1.1-13 